\title{
ХРОМАТОГРАФІЧНИЙ ПРОФІЛЬ ГІДРОКСИКОРИЧНИХ КИСЛОТ СУХОГО ЕКСТРАКТУ ПАГОНІВ ЧОРНИЦІ
}

\section{Л. В. Вронська}

\author{
Тернопільський національний медичний університет імені І. Я. Горбачевського мОз \\ України \\ vronska_liudmyla@ukr.net
}

\section{ІНФОРМАЦІЯ}

Надійшла до редакції / Received: 09.12 .2019

Після доопрацювання / Revised: 13.12.2019

Прийнято до друку / Accepted: 16.12.2019

\section{Ключові слова:}

пагони чорниці;

сухий екстракт;

гідроксикоричні кислоти; високоесрективна

рідинна хроматографрія; хроматографрічний профріль; електронні спектри поглинання гідроксикоричних кислот.

\section{АНОТАЦІЯ}

Мета роботи. Вивчення профріля гідроксикоричних кислот сухого екстракту пагонів чорниці методом високоефективної рідинної хроматографії.

Матеріали і методи. Матеріалом для дослідження були сухі екстракти пагонів чорниці, отримані методом дробної мацерації 3 подрібнених пагонів чорниці вітчизняного походження за допомогою спиртово-водного екстрагенту із різним вмістом етанолу. Для ідентифрікації гідроксикоричних кислот застосовували стандартні зразки гідроксикоричних кислот (SigmaAldrich, Fluka). ВЕРХ-дослідження проводили на рідинному хроматограсрі 3 детектором діодною матрицею («Waters 2960», США). Використовували хроматографрічну колонку XTerra C18 («Waters», США) розміром 250×4,6 мм (5 мкм) при температурі $(25 \pm 1)^{\circ} \mathrm{C}$.

Результати й обговорення. BEPX-профілі сухого екстракту пагонів чорниці містили хроматографрічні піки, що відповідали часу утримування хлорогенової, кофейної, фрерулової, транс-п-кумарової і 3-гідроксикоричної кислот. Шляхом аналізу їхніх електронних спектрів поглинання було підтверджено присутність лише хлорогенової і кофейної кислот. Речовина 3 відносним часом утримування 4,2 (відносно хлорогенової кислоти) характеризується спектром поглинання, ідентичним спектрові хлорогенової кислоти, що вказує на приналежність цієї речовини до гідроксикоричних кислот. ВЕРХ-профріль екстракту містить хроматографрічні піки трьох речовин, спектри поглинання яких є подібними зі спектром транс-п-кумарової кислоти. Ймовірно, вони можуть належати до ізомерів чи похідних цієї кислоти. Були проведені BEPXдослідження профілів гідроксикоричних кислот сухих екстрактів, отриманих за допомогою екстрагентів із різним вмістом етанолу. Встановлено, що вміст кофейної кислоти в сухому екстракті підвищується, а вміст хлорогенової знижується зі зменшенням вмісту етанолу в екстрагенті. Це, ймовірно, пов'язано 3 інтенсифрікацією процесів гідролізу хлорогенової кислоти до кофейної. Це спонукає до глибшого вивчення даного процесу як з метою оптимізації технології, так і дослідження стабільності й умов зберігання готового екстракту.

Висновки. Для ідентифрікації сухого екстракту пагонів чорниці доцільно застосувати метод хроматографічного «відбитка» шляхом виявлення у BEPX-профрілях екстракту, отриманих при довжині хвилі детектування 270 і 330 нм хлорогенової, кофейної, невідомої гідроксикоричної (відносний час утримування 4,2 відносно хлорогенової кислоти) та похідних транс-п-

ISSN 2312-0967. Pharmaceutical review. 2019. № 4 
кумарової кислот. Одночасно 3 дослідженням ВЕРХ-профрілів необхідне порівняння спектрів поглинання речовин із відповідним часом утримування. Зважаючи на високий вміст окремих гідроксикоричних кислот (хлорогенової, кофрейної), вміст окремо взятої кислоти чи/або суми гідроксикоричних кислот, у перерахунку на хлорогенову, необхідно обрати як один із кількісних критеріїв якості сухого екстракту.

Вступ. 3 огляду на біологічну активність, найбільш важливими з фенолокислот, присутніх у лікарській рослинній сировині (ЛРС), є похідні коричної і бензойної кислот. У процесі біосинтезу з фенілаланіну при дезамінуванні утворюється корична кислота, а з неї її похідні - гідроксикоричні кислоти [1-6]. Вони $\epsilon$ важливим класом речовин, які ідентифрікують і кількісно визначають у лікарській рослинній сировині (ЛРС), екстрактах і готових лікарських засобах (ГЛЗ) рослинного походження [7-12]. Хроматографрічні профрілі похідних бензойної і коричної кислоти дозволяють встановлювати тотожність одних видів 3-поміж інших [7]. Представникам цього класу речовин властиві дії: цукрознижувальна [1], антиоксидантна [1-3], захисна стосовно клітин ендотелію [5], протизапальна $[4,6]$.

Саме цей клас речовин часто обирають як маркерні речовини у процесі стандартизації ЛРС, екстрактів і ГЛЗ. Згідно з монографріями на ЛРС і екстракти, представлені у Державній Фармакопеї України другого видання з трьома доповненнями, при ідентифікації близько 50 видів сировини та екстрактів застосовують як маркерні речовини гідроксикоричні кислоти, які присутні в об'єкті аналізу або спеціально використовуються для детального опису хроматографрічного профріля [13-16]. Хлорогенова кислота частіше від інших ідентифрікується або обирається для характеристики хроматографрічного профрілю як найбільш розповсюджена серед БАР ЛРС, а також у зв'язку із їі доступністю у лабораторіях. Хлорогенова кислота згадується в описі TШХ-профрілів більше 20 видів ЛРС: бобівника трилистого листя, бузини квіток, глоду плодів і глоду листя та квіток, золотушника і золотушника європейського, споришу, ясена листя, кульбаби лікарської коренів та трави з коренями, пижма квіток та ін., а також глоду листя та квіток екстракту рідкого, звіробою екстракту сухого, ромашки екстракту рідкого; вона - обов'язковий кількісний критерій при стандартизації артишоку листя екстракту сухого [13-16].

Пагони чорниці - ЛРС, яка містить різні класи БАР, у тому числі і гідроксикоричні кислоти, але вивчення їхнього складу і вмісту $є$ недостатнім. Склад гідроксикоричних кислот є більш дослідженим для плодів чорниці, які описані у світових фрармакопеях як ЛРС, тоді як пагони і листя були введені у ДФУ як національний додаток [15]. При їхній стандартизації для ідентифрікації скористалися порівнянням ТШХ- профрілів досліджуваного зразка сировини 3 фрармакопейним стандартним зразком ДФУ чорниці екстракту, при цьому не ідентиоріковані жодна із зон, присутніх у профрілях.

Мета роботи - вивчення профрілю гідроксикоричних кислот сухого екстракту пагонів чорниці методом високоесрективної рідинної хроматографії.

Матеріали і методи. Матеріалом для дослідження були сухі екстракти, отримані методом дробної мацерації з подрібнених пагонів чорниці вітчизняного походження за допомогою спиртово-водного екстрагенту із різним вмістом етанолу. Для ідентифікації гідроксикоричних кислот застосовували стандартні зразки хлорогенової, ферулової, розмаринової, кофейної, транс-коричної, транс-3-гідроксикоричної, транс-п-кумарової кислот (Sigma-Aldrich, Fluka). Вивчення якісного складу і визначення кількісного вмісту гідроксикоричних кислот здійснювали методом високоефективної рідинної хроматографії (BEPX). BEPX-дослідження проводили на рідинному хроматограсрі Waters 3 детектором діодною матрицею («Waters 2690», США), хроматографічні предколонку і колонку XTerra C18 («Waters», США) розміром 250x4,6 мм (5 мкм) при температурі $(25 \pm 1)^{\circ} \mathrm{C}$ в умовах градієнтного елюювання. Рухома фраза А: фросфрорна кислота - ацетонітрил - вода (1:19:80), рухома фраза В: фросфрорна кислота - метанол - ацетонітрил (1:40:59); програма градієнта: 0-20 хв - фраза А лінійно зі 100 до 55 \%; 20-25 хв - фраза А лінійно 355 до 0 \%; 25-35 хв - фраза А лінійно $з$ д до 100 \%; 3545 хв - $100 \%$ фраза А. Швидкість рухомої фрази 1,2 мл/хв; спектрофотометричне детектування при довжині хвилі 330 нм; об'єм інжекції - 20 мкл.

Розчини стандартних зразків і досліджуваних екстрактів готували шляхом розчинення наважок відповідних речовин-стандартів (20 мг / 100 мл) та екстрактів (100 мг / 25 мл) в етанолі (50 \% (об/об)) з наступним розведенням до досягнення бажаної концентраціï.

Результати й обговорення. У зазначених умовах хроматографування речовини вибраних стандартів гідроксикоричних кислот добре розділяються, їхні окремі хроматографрічні та спектральні характеристики наведені в таблиці 1.

У тих же умовах хроматографрування було вивчено хроматографічний профіль гідроксикоричних кислот сухого екстракту пагонів чорниці (рис. 1). Як випливає з представленої хроматограми, при довжині хви-

ISSN 2312-0967. Фармацевтичний часопис. 2019. № 4 
Фітохімічні дослідження Phytochemical researches

Таблиця 1

Характеристики гідроксикоричних кислот в умовах хроматографрування

\begin{tabular}{|l|c|c|c|c|}
\hline \multicolumn{1}{|c|}{ Речовина } & $\begin{array}{c}\text { Час } \\
\text { утримування, хв }\end{array}$ & $\begin{array}{c}\text { Коефріцієнт } \\
\text { симетрії }\end{array}$ & $\begin{array}{c}\text { Число теоретичних } \\
\text { тарілок (ЄФ) }\end{array}$ & $\begin{array}{c}\text { Довжина хвилі максимуму } \\
\text { поглинання, нм }\end{array}$ \\
\hline Хлорогенова кислота & 3.479 & 1.198 & 5780 & 325,240 (плече), 215 \\
\hline Косрейна кислота & 4.828 & 1.106 & 9496 & $323,239-240,216$ \\
\hline Транс-п-кумарова кислота & 6.765 & 1.165 & 15617 & $309,224-225$ \\
\hline Ферулова кислота & 7.470 & 1.080 & 17918 & $322,234,215$ \\
\hline $\begin{array}{l}\text { Транс-3-гідроксикорична } \\
\text { кислота }\end{array}$ & 8.201 & 1.129 & 21829 & 320 (плече), 276-278, 230, \\
\hline Розмаринова кислота & 9.793 & 1.043 & 212 \\
\hline Транс-корична кислота & $14.624^{\star}$ & $1,012^{\star}$ & $36895^{\star}$ & 328,216 (плече) \\
\hline
\end{tabular}

Примітка. * - дані для хроматограми, отриманої при довжині хвилі детектування 275 нм.

лі детектування 330 нм, виявлено низку чітких відокремлених від інших хроматограорічних піків, два 3 яких за часами утримування та електронним спек- тром поглинання при своєму часі утримування відповідають хлорогеновій (3,46 хв) і кофейній (4,77 хв) кислотам (рис. 2).

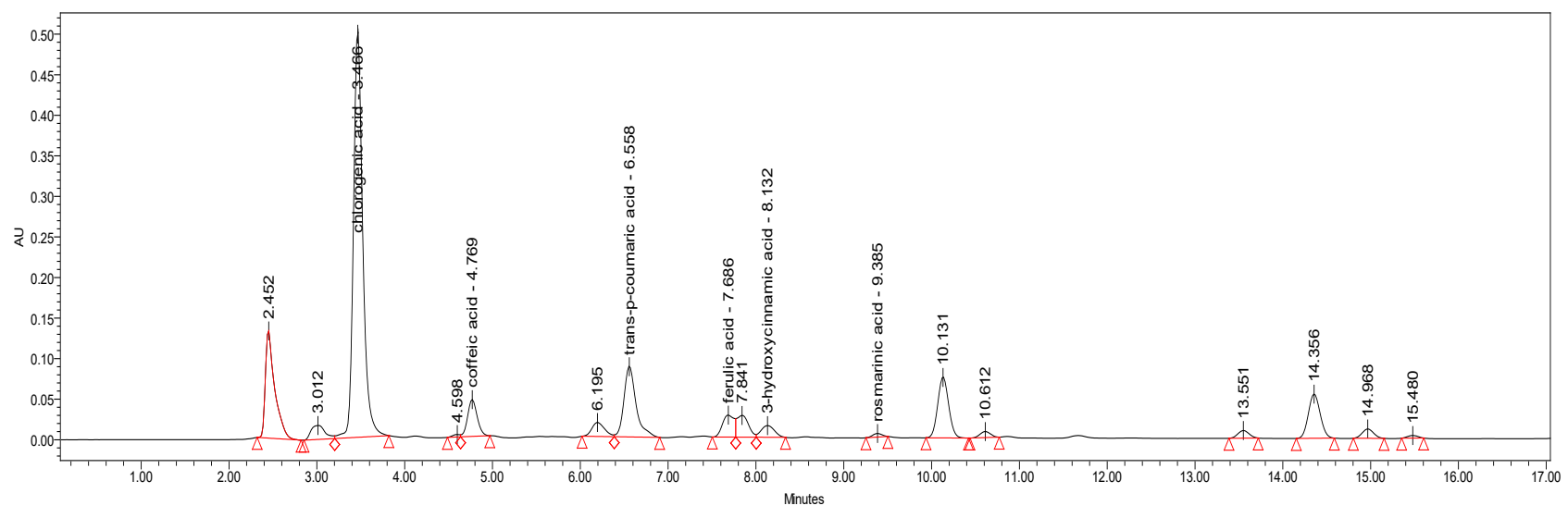

Рис. 1. Типова хроматограма випробовуваного розчину сухого екстракту пагонів чорниці, отримана при довжині хвилі детектування 330 нм.
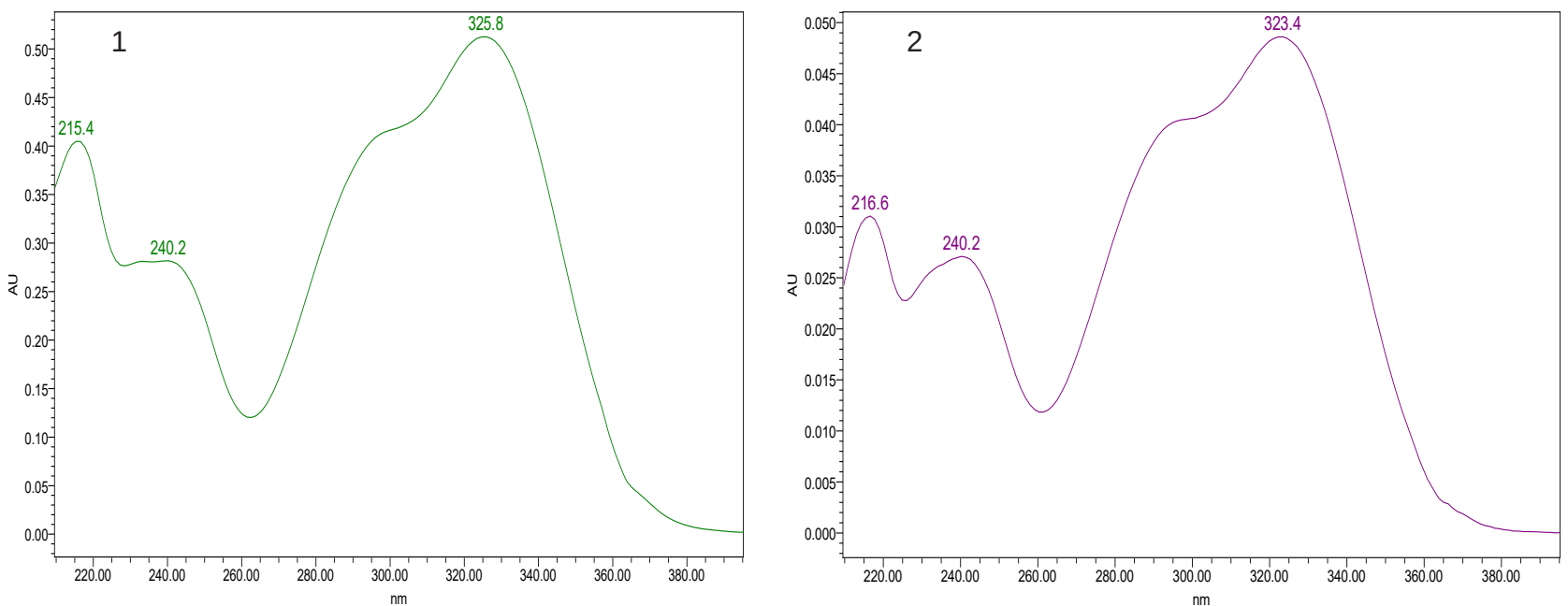

Рис. 2. Електронні спектри поглинання хлорогенової кислоти при часі утримування 3,466 хв (1) і кофейної кислоти при часі утримування 4,769 хв (2), отримані для випробовуваного розчину сухого екстракту пагонів чорниці.

ISSN 2312-0967. Pharmaceutical review. 2019. № 4 
Фітохімічні дослідження

Phytochemical researches

Хроматографрічний пік при часі утримування 6,558 хв ідентифрікується в автоматичному режимі інтегрування та ідентифрікації як транс-пкумарова кислота, проте спектр поглинання речовини, яка відображається цим піком на хроматограмі, не відповідає спектру поглинання трансп-кумарової кислоти, отриманому з хроматограми розчину порівняння (рис. 3). В спектрі невідомого компонента $€$ максимуми поглинання при 254 і 353 нм, що не відповідає максимумам поглинання транс-п-кумарової кислоти - 225 і 309 нм відповідно.

Хроматографрічний пік при часі утримування 7,686 хв автоматично ідентифікується як фрерулова кислота, але спектр поглинання ферулової кислоти 3 хроматограми стандартного зразка має інший вигляд (рис. 4) і час утримування дещо різниться для стандарту $(7,470$ хв), тому ця речовина не $є$ фреруловою кислотою.

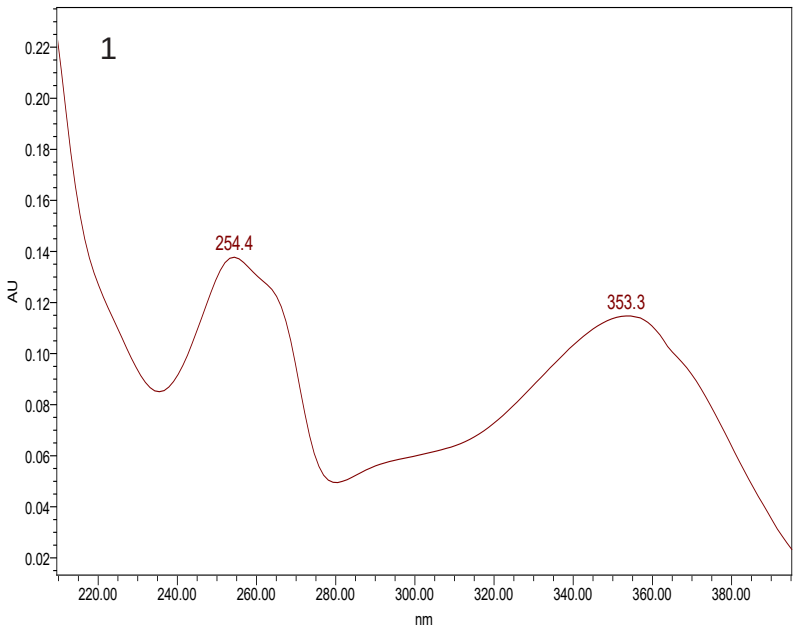

Транс-3-гідроксикоричній кислоті на хроматограмі стандартного розчину відповідає пік із часом утримування 8,201 хв. На хроматограмі, отриманій для випробовуваного розчину сухого екстракту чорниці, вона ідентиорікується як пік речовини з часом утримування 8,13 хв. Проте порівняння їхніх спектрів поглинання свідчить про іншу природу речовини, час утримування якої збігається 3 часом утримування транс-3-гідроксикоричної кислоти (рис. 5).

Пік невідомої речовини 3 часом утримування 9,385 хв на хроматограмі випробовуваного розчину сухого екстракту пагонів чорниці, шляхом автоматичного порівняння хроматограм, ідентисрікується як розмаринова кислота. Час утримування речовини дещо відрізняється від часу утримування власне розмаринової кислоти (табл. 1) і спектри поглинання дуже різняться, що вказує на відсутність розмаринової кислоти серед біологічно активних речовин досліджуваного екстракту (рис. 6 і рис. 4).

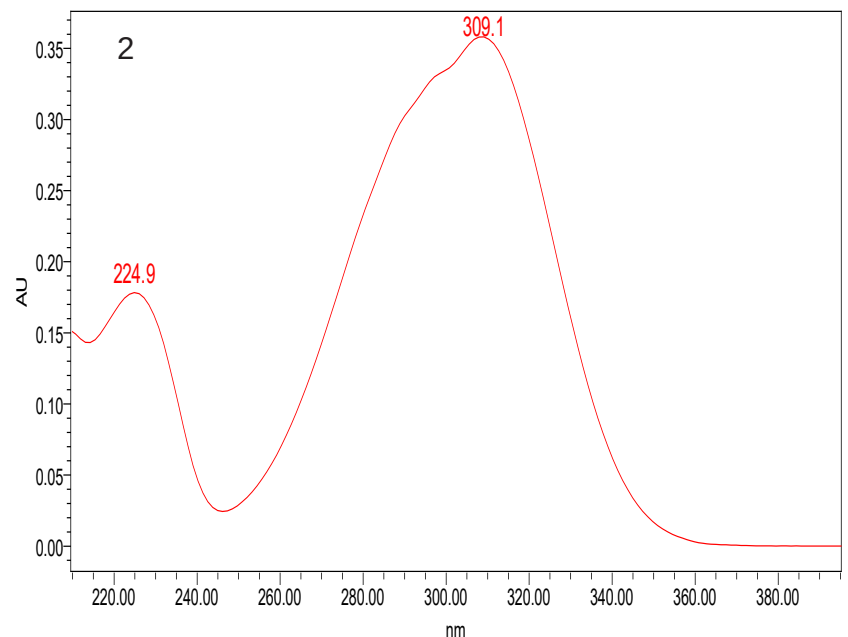

Рис. 3. Електронні спектри поглинання невідомої речовини при часі утримування 6,558 хв (1) і транс-п-кумарової кислоти при часі утримування 6,765 хв (2).
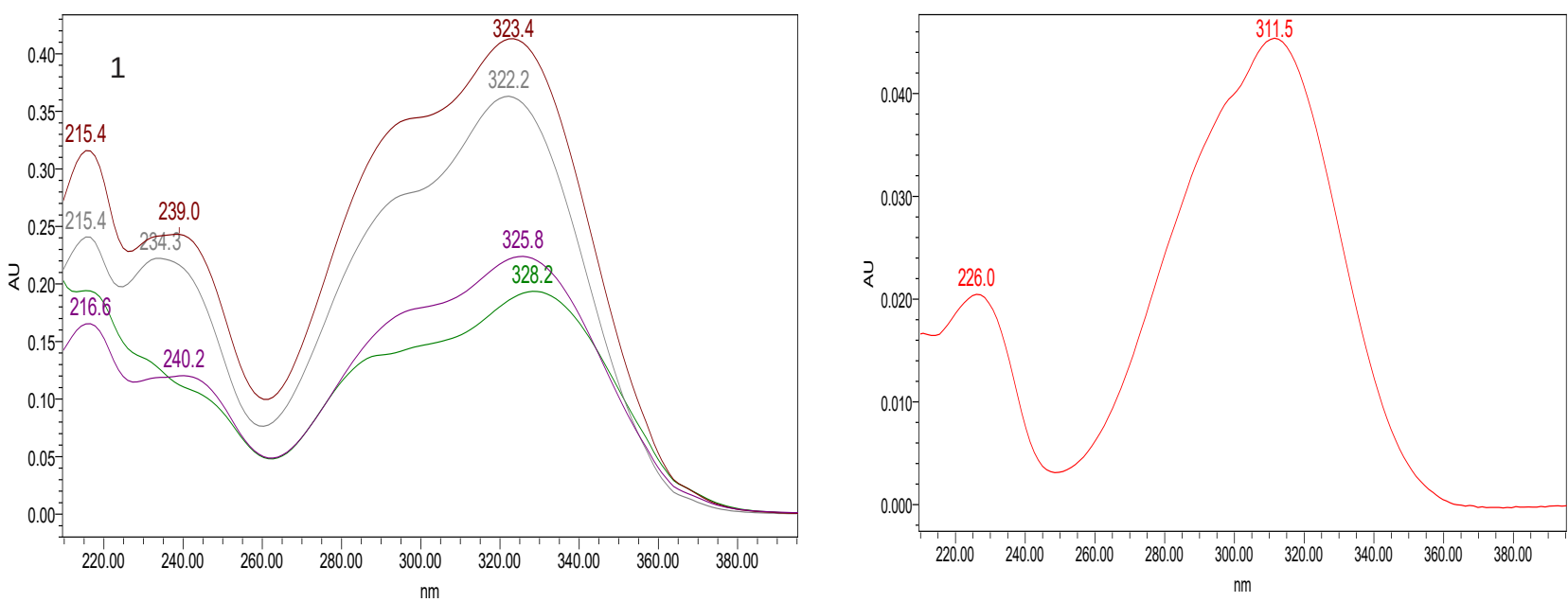

Рис. 4. Електронні спектри поглинання: 1 - стандартів кофрейної $\left(\lambda_{\max }=323,4\right.$ нм), фрерулової $\left(\lambda_{\max }=322,2\right.$ нм), хлорогенової $\left(\lambda_{\max }=325,8\right.$ нм) і розмаринової $\left(\lambda_{\max }=328,2\right.$ нм) кислот при їхньому часі утримування; $2-$ невідомої речовини при часі утримування 7,686 хв.

ISSN 2312-0967. Фармацевтичний часопис. 2019. № 4 
Фітохімічні дослідження Phytochemical researches
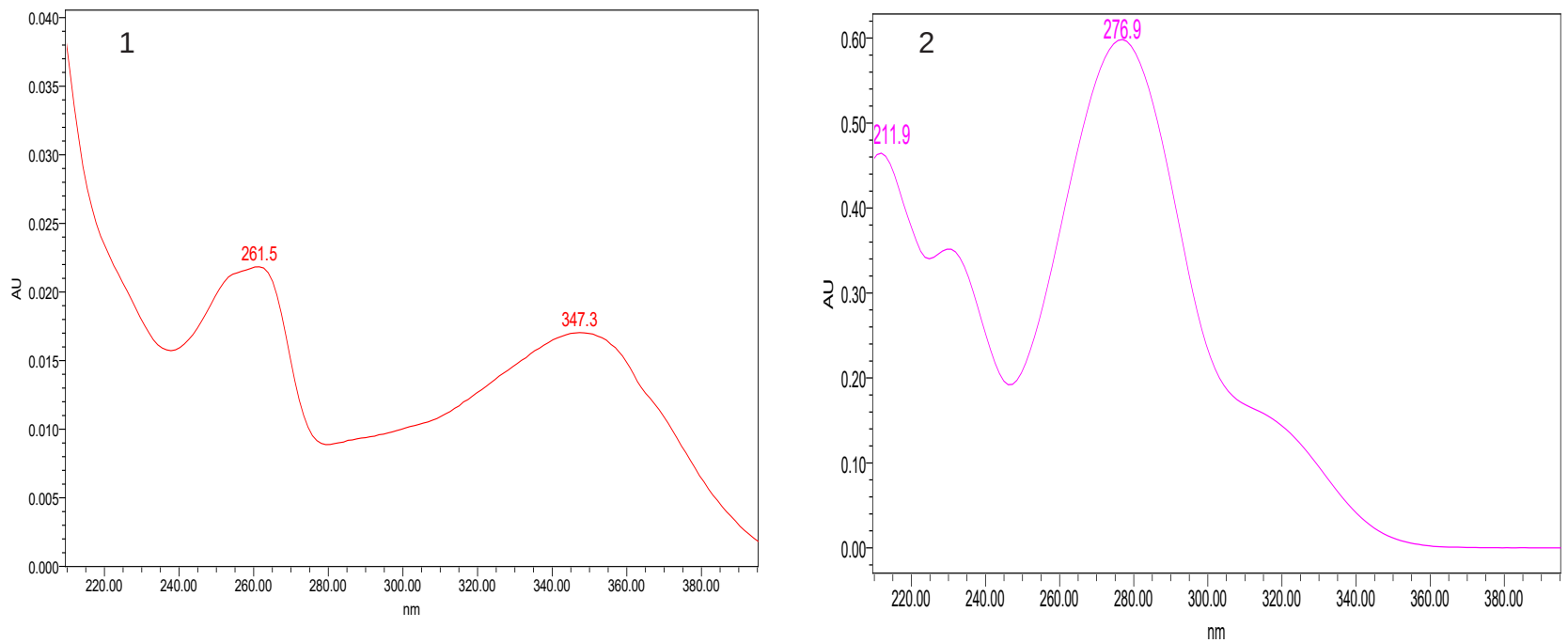

Рис. 5. Електронні спектри поглинання невідомої речовини при часі утримування 8,130 хв (1) і транс-3гідроксикоричної кислоти при часі утримування 8,201 хв (2).

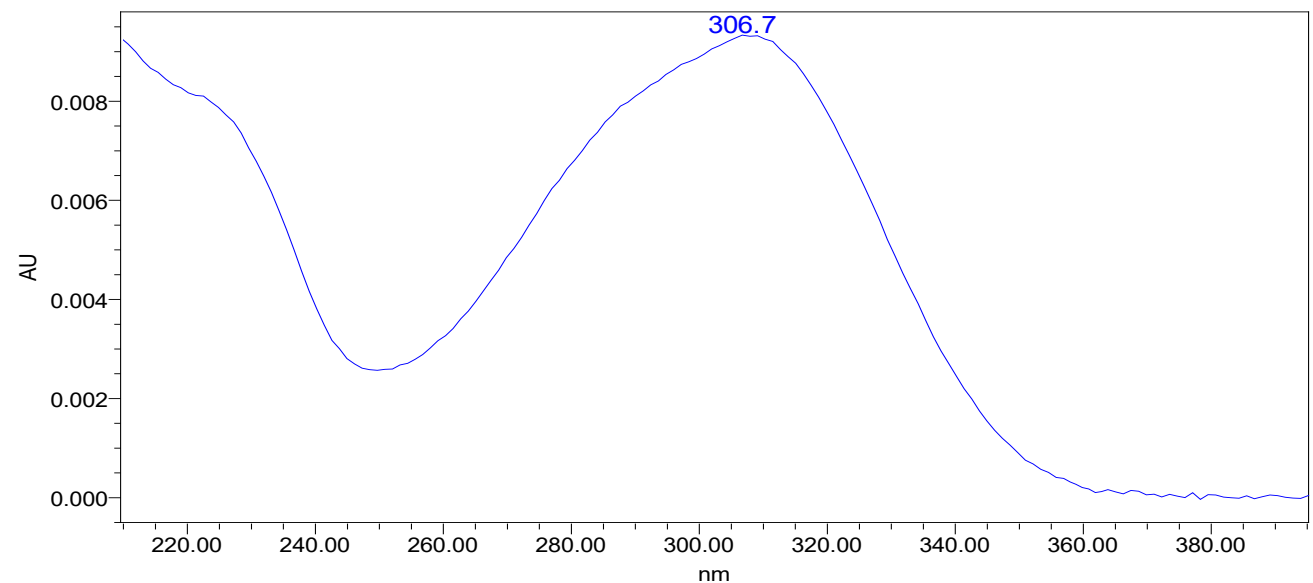

Рис. 6. Електронний спектр поглинання речовини при часі утримування 9,385 хв, отриманий з хроматограми випробовуваного розчину сухого екстракту пагонів чорниці.

На хроматограмі випробовуваного розчину сухого екстракту пагонів чорниці при довжині хвилі детектування 330 нм виявляються ще декілька речовин з часом утримування відповідно: 10,131 хв; 10,612 хв; 13,551 хв; 14,356 хв і 14,968 хв. Електронні спектри поглинання цих речовин при їхньому часі утримування представлені на рисунку 7.

Аналіз ходу кривих світлопоглинання дозволяє стверджувати, що речовина із часом утримування 14,356 хв належить до гідроксикоричних кислот, ії спектр дуже подібний до абсорбційного спектра хлорогенової кислоти. Її будову можна буде встановити у ході хромато-мас-дослідження. Речовини із часом утримування 7,686, 10,131 і 14,968 хв є представниками одного класу, їхні спектри є практично ідентичними між собою і спектром поглинання транс-пкумарової кислоти. Таким чином, це можуть бути її ізомери або похідні, оскільки транс-п-кумарова кислота у використаних умовах має час утримування
6,765 хв. Речовині з часом утримування 13,551 хв відповідає спектр поглинання із максимумом при 253 нм і широким у ділянці 373 нм, її будова, як і інших не ідентифікованих, може бути встановлена у хромато-мас-спектрометричному дослідженні.

На рисунку 8 наведені хроматограми випробовуваного розчину сухого екстракту пагонів чорниці, отримані в різних умовах детектування.

Аналіз представлених хроматограм дозволяє стверджувати, що для об'єктивної ідентифрікації сухого екстракту пагонів чорниці слід отримувати BEPXхроматограсрічні профрілі при 330 і 270 нм, на обох хроматограмах повинні ідентифрікуватись всі три речовини, які належать до гідроксикоричних кислот хлорогенова (3,47 хв), косрейна (4,77 хв) і невідома 3 відносним часом утримування відносно хлорогенової кислоти близько 4,2.

Гідроксикоричні кислоти є достатньо лабільними речовинами, тому динаміка їхнього вмісту -

ISSN 2312-0967. Pharmaceutical review. 2019. № 4 
Фітохімічні дослідження

Phytochemical researches
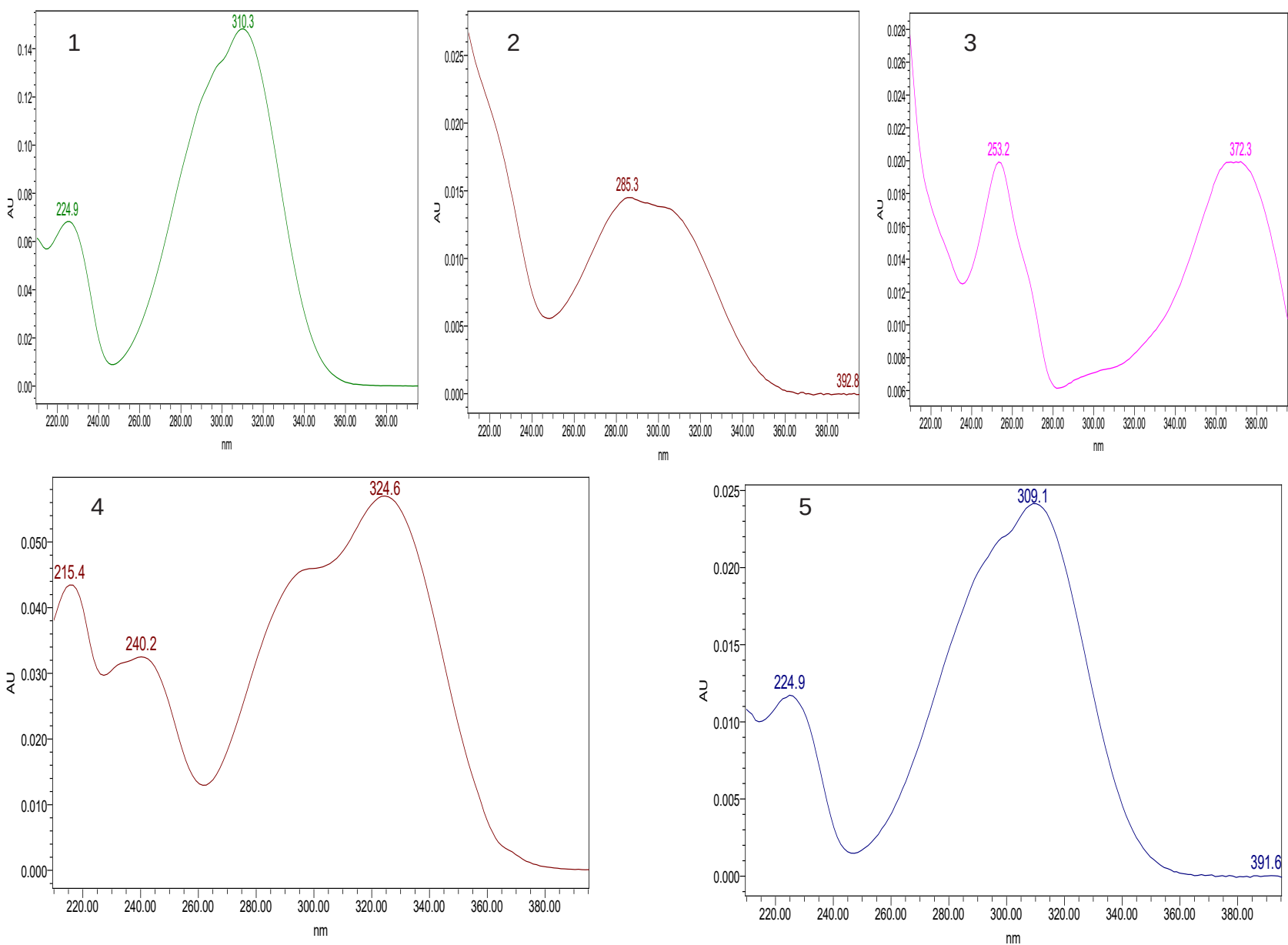

Рис. 7. Електронні спектри поглинання речовин, які на хроматограмі випробовуваного розчину виявляються піками з часом утримування: 1 - 10,131 хв; 2 - 10,612 хв; 3 - 13,551 хв; 4 - 14,356 хв; 5 - 14,968 хв.

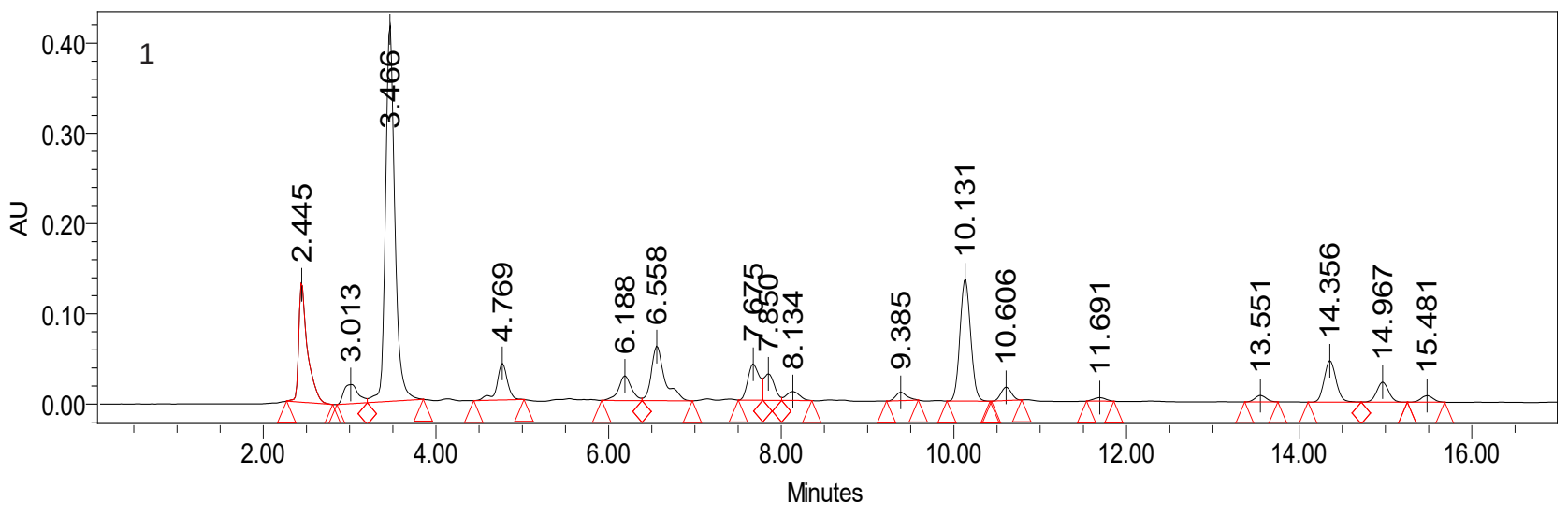

Рис. 8. Типові хроматограми випробовуваного розчину сухого екстракту пагонів чорниці, отримані при довжині хвилі детектування: 1 - 300 нм.

ISSN 2312-0967. Фармацевтичний часопис. 2019. № 4 

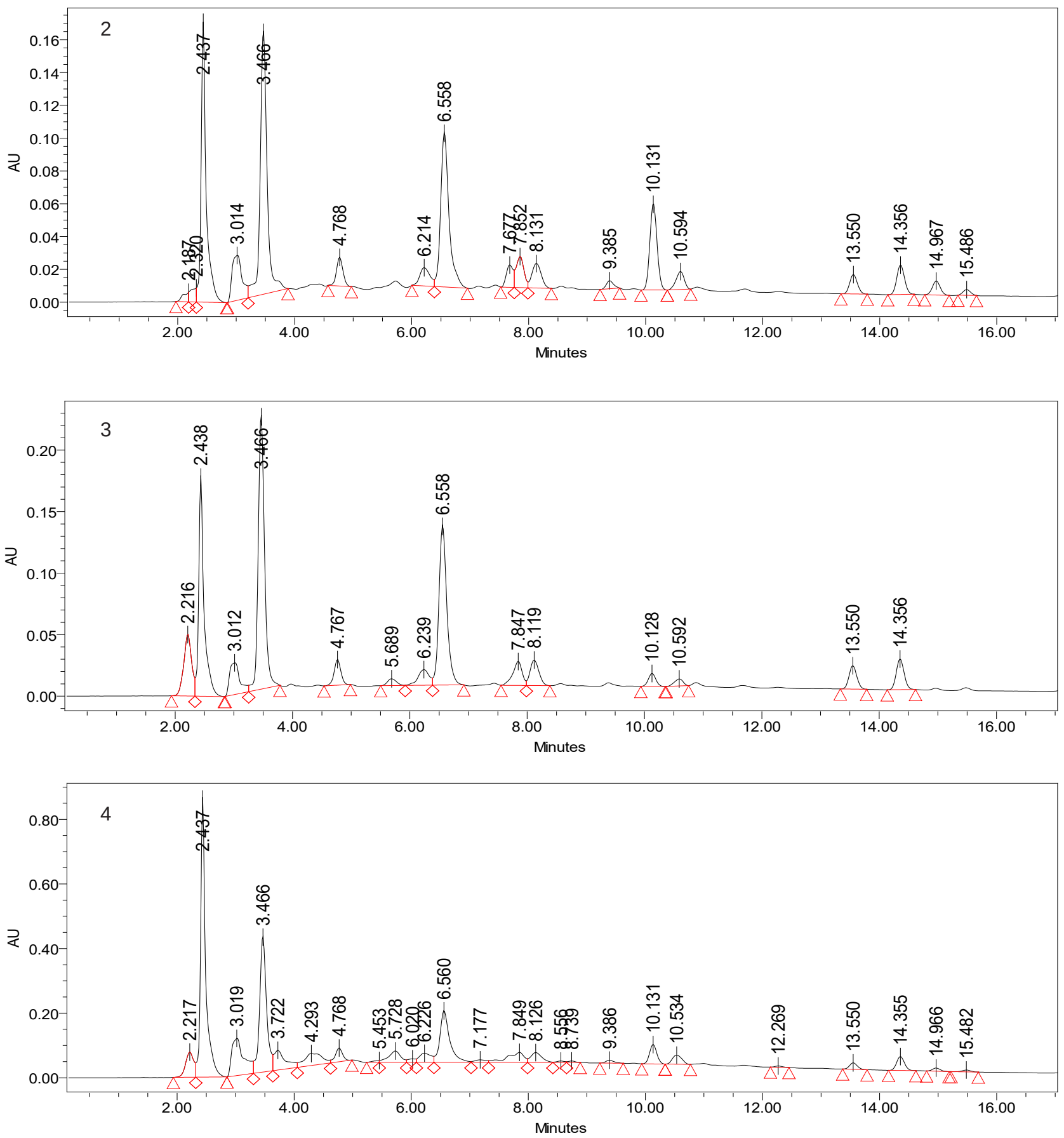

Рис. 8. (продовження) Типові хроматограми випробовуваного розчину сухого екстракту пагонів чорниці, отримані при довжині хвилі детектування: 1 - 300 нм, 2 - 270 нм, 3 - 250 нм, 4 - 215 нм.

важливий параметр контролю у процесі розробки технології і методик контролю якості екстракту, вивчення біологічної дії, стабільності і встановлення терміну його придатності. В зв'язку з цим, було досліджено вплив концентрації етанолу в екстрагенті на вигляд BEPX-профріля отримуваних сухих екстрактів (рис. 9). Як випливає з представлених хроматограм і здійснених розрахунків, підвищення вмісту етанолу в екстра- генті супроводжується зниженням вмісту кофейної кислоти і зростанням вмісту хлорогенової кислоти в отримуваних сухих екстрактах (табл. 2). Вміст гідроксикоричної кислоти невстановленої будови (з часом утримування 14,3-14,6 хв) також залежить від вмісту етанолу в екстрагенті і знижується із підвищенням концентрації етанолу, що, ймовірно, пов'язано з гідролізом у розчинах із нижчим вмістом етанолу.

ISSN 2312-0967. Pharmaceutical review. 2019. № 4 

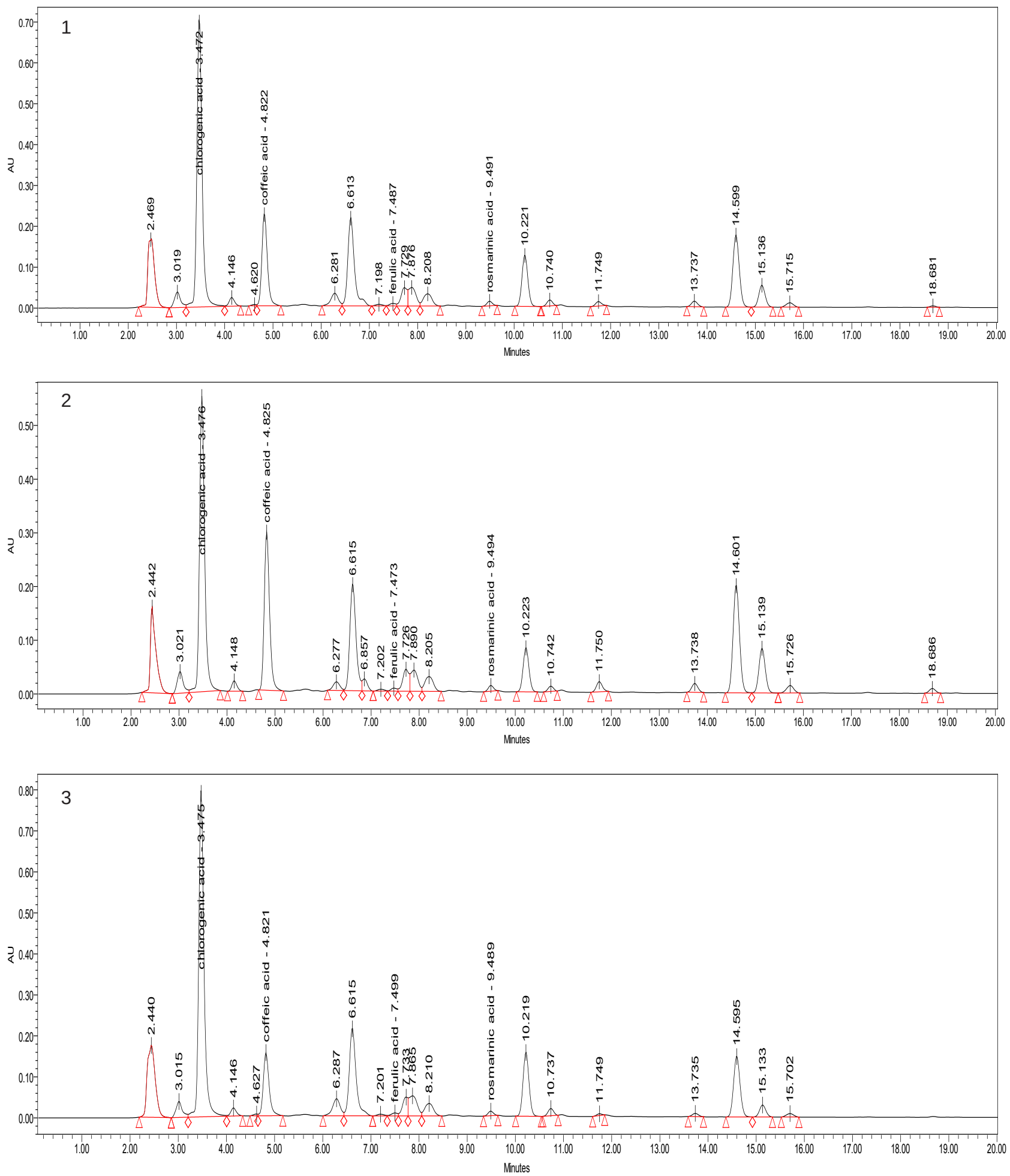

Рис. 9. Типові хроматограми випробовуваних розчинів сухих екстрактів пагонів чорниці, отриманих за допомогою екстрагентів із вмістом етанолу (об/об): 1 - 40 \%; 2 - 50 \%; 3 - 60 \%. Довжина хвилі детектування 330 нм. 


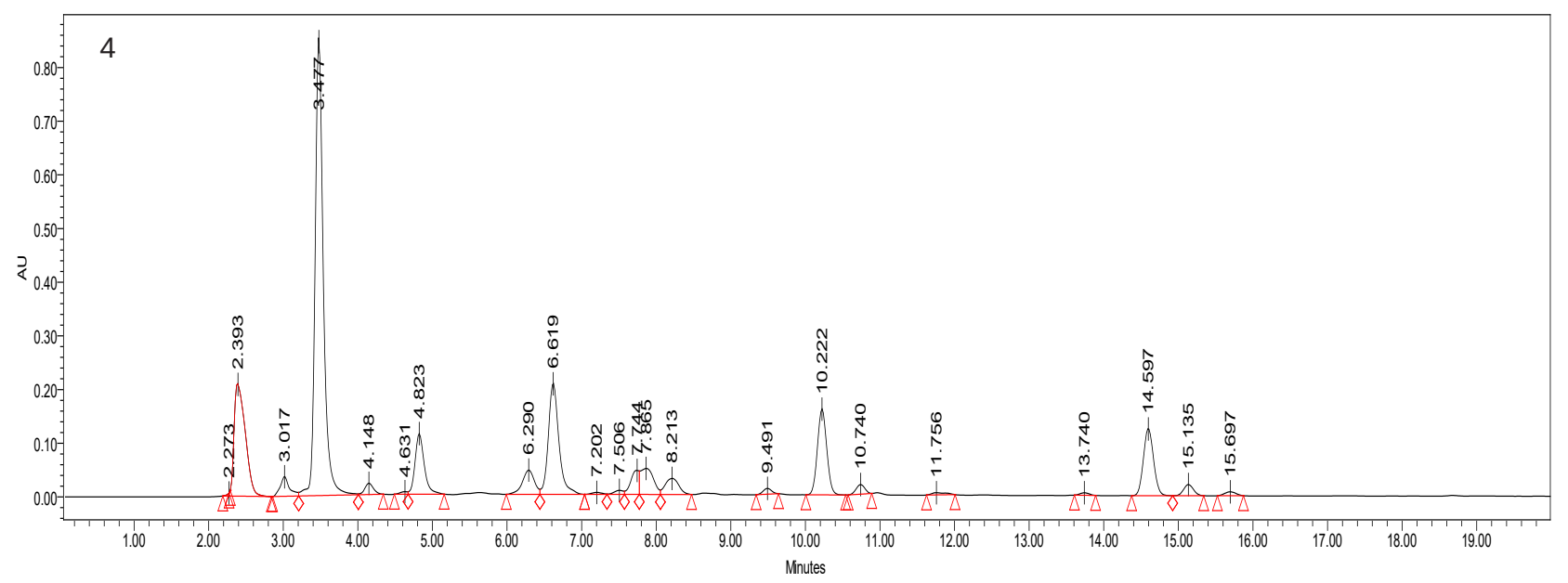

Рис. 9. (продовження) Типові хроматограми випробовуваних розчинів сухих екстрактів пагонів чорниці, отриманих за допомогою екстрагентів із вмістом етанолу (об/об): 1 - 40 \%; 2 - 50 \%; 3 - 60 \%; 4 - 70 \%. Довжина хвилі детектування 330 нм.

Таблиця 2

Результати визначення вмісту гідроксикоричних кислот у сухих екстрактах пагонів чорниці $(\mathrm{n}=5, \mathrm{P}=0,95)$

\begin{tabular}{|c|c|c|c|}
\hline \multirow{2}{*}{$\begin{array}{c}\text { Вміст етанолу в } \\
\text { екстрагенті, } \\
\% \text { (об/об) }\end{array}$} & Хлорогенова кислота & Косрейна кислота & $\begin{array}{c}\text { Площа піка } \\
\text { гідроксикоричної кислоти } \\
(\tau=14,3-14,6 \text { хв) }\end{array}$ \\
\hline 40 & $3,58 \pm 0,02$ & $0,91 \pm 0,02$ & $2350108(* 100 \%)$ \\
\hline 50 & $4,51 \pm 0,02$ & $0,69 \pm 0,01$ & $1987551(* 84,6 \%)$ \\
\hline 60 & $5,05 \pm 0,02$ & $0,49 \pm 0,01$ & $1671563(* 71,1 \%)$ \\
\hline 70 & $5,72 \pm 0,03$ & $0,39 \pm 0,01$ & $1471687(* 62,6 \%)$ \\
\hline
\end{tabular}

Примітка: * - площа піка гідроксикоричної кислоти невстановленої будови перерахована на 100 мг сухого екстракту з врахуванням вмісту вологи та нормалізована площа (\%), виходячи із прийняття за 100 \% її вміст в екстракті, отриманому за допомогою 40 \% (об/об) етанолу.

Науковці розглядають гідроксикоричні кислоти як важливий клас речовин, який у випадку пагонів чорниці та екстрактів на їхній основі пов'язують з гіпоглікемічною дією. Механізм такої дії тривало дискутується і продовжує вивчатись для засобів з чорниці [1, 5, 6, 17-22]. Зокрема, при дослідженні зв'язку структури молекули гідроксикоричної кислоти та її антиоксидантної активності $[18,21,22]$ встановлено, що для молекул, які містять орто-дигідрокси- або 4-гідрокси-3-метокси- групи, характерна вища антиоксидантна дія, як і у випадку зростання числа гідроксильних груп. Проте останнє спостерігається у гідрофрільному середовищі, тоді як у ліпофрільних - кращими антиоксидантами є дигідроксипохідні. Наявність подвійного зв'язку у бічному радикалі позитивно позначається на антиоксидантній дії. Етерифрікація короткими радикалами $\left(\mathrm{C}_{1}-\mathrm{C}_{4}\right)$ приводить до незначного зниження антиоксидантної активності, але у зв'язку із зростанням ліпофрільності молекули підвищується ії̈ коефріцієнт розподілу, що сприяє ії проникненню і «застосуванню» у більш ліпоорільних середовищах - інгібується пероксидація ліпідів [18]. У ре- зультаті інших досліджень встановлено, що молекули із елементами хінонів і лактонів або речовини із 7-оксопірановим елементом викликають інгібування $\alpha$-амілази - при цьому має значення просторове розташування гідрокси-груп [23], зокрема, хлорогенова (IC ${ }_{50}=1,4$ мM) поступається ізохлорогеновій (IC ${ }_{50}=0,56$ мM); наявність подвійного зв'язку в бічному радикалі $є$ важливою для можливості інгібування а-амілази - дигідрокофейна кислота поступається кофейній.

Отже, біологічно важливими і характеристичними гідроксикоричними кислотами сухих екстрактів пагонів чорниці є хлорогенова і кофейна кислоти та неідентифрікована сполука, яка у спектрі поглинання $€$ ідентичною хлорогеновій, але характеризується значно більшим часом утримування. Дослідження гідроксикоричних кислот у плодах і надземній частині (стебла і листя) представлені у роботах іноземних авторів [24, 25]. Методом ультрависокоесрективної рідинної хроматографії 3 хромато-мас детектуванням авторами [24] у плодах чорниці, зібраних у різних регіонах Туреччини, було ідентисріковано 4 гідроксикоричні кислоти: кофейна, п-кумарова, фрерулова і

ISSN 2312-0967. Pharmaceutical review. 2019. № 4 
хлорогенова. При цьому у вільному стані у співмірній дуже незначній кількості було ідентифріковано і кількісно визначено дві: кофейну і п-кумарову; в естерифрікованій фрормі - три, з них - кофейну і п-кумарову у співмірній і в найбільшій кількості та в незначній кількості фрерулову; у глікозидованій фрормі ідентифікували всі чотири, при цьому вміст кофейної і п-кумарової був найбільшим, а кількості хлорогенової і фрерулової були незначними і співмірними.

Отримані результати найбільше збігаються із даними авторів [25], які вивчали, серед інших, гідроксикоричні кислоти надземної частини чорниці, а саме - стебел і листя. Екстрагування гідроксикоричних кислот за допомогою водно-метанольних екстрагентів дозволило авторам виявити різницю у френольних просрілях тканин листя і стебел і різницю у здатності екстрагентів забезпечувати максимальне вилучення, в результаті чого було зроблено висновок про вищий ступінь глікозилювання френольних сполук, в тому числі і гідроксикоричних кислот, у стеблах. У листі домінуючою сполукою була хлорогенова кислота, а в стеблах - похідне паракумарової кислоти. Кофейна кислота ідентифрікувалась після лужної обробки сировини стебел.

Таким чином, спостережувана залежність вмісту кофейної кислоти у сухому екстракті пагонів чорниці від вмісту етанолу в екстрагенті цілком узгоджується із трактуванням авторів [25]. Для забезпечення якості сухого екстракту пагонів чорниці, а саме - отримання передбачуваного цукрознижувального ефекту, важливим $€$ контроль складу (метод хроматографрічного «відбитка») і вмісту гідроксикоричних кислот, який, як було показано, може змінюватися в процесі використання різних екстрагентів. Ці зміни, ймовірно, також можуть виникати в результаті недотримання технології екстракту чи готового лікарського засобу 3 ним, а також у процесі зберігання.

Висновки. 1. Вивчено склад гідроксикоричних кислот сухого екстракту пагонів чорниці. В результаті дослідження ідентифріковано хлорогенову і кофейну кислоти, виявлено гідроксикоричну кислоту, спектр поглинання якої є ідентичним хлорогеновій, а також ще три сполуки, які, відповідно до спектрів поглинання, можуть бути похідними пара-кумарової кислоти.

2. При ідентисрікації сухого екстракту пагонів чорниці слід застосовувати метод хроматографрічного «відбитка». Отримуючи ВЕРХ-профрілі при 330 і 270 нм необхідно ідентифікувати три речовини, які належать до гідроксикоричних кислот - хлорогенову (3,47 хв), кофейну (4,77 хв) і невідому (14,4-14,6 хв або з відносним часом утримування близько 4,2 відносно хлорогенової кислоти). В процесі ідентифрікації сухого екстракту пагонів чорниці метод хроматографічного «відбитка» слід поєднувати 3 одночасним дослідженням спектрів поглинання кожної 3 ідентифрікованих сполук.

3. Зважаючи на високий вміст окремих гідроксикоричних кислот (не менше 4,5 \% хлорогенової) необхідно обрати вміст окремо взятої кислоти чи/або суми гідроксикоричних кислот у перерахунку на хлорогенову як один із кількісних критеріїв якості в процесі розробки технології і методик контролю якості екстракту та засобів на його основі, дослідження їхньої стабільності.

Конфлікт інтересів: відсутній.

Conflicts of interest: author has no conflict of interest to declare.

\section{CHROMATOGRAPHIC PROFILE OF THE HYDROXYCINNAMIC ACIDS OF BILBERRY SHOOTS DRY EXTRACT}

\section{V. Vronska \\ I. Horbachevsky Ternopil National Medical University vronska_liudmyla@ukr.net}

The aim of the work. Study of hydroxycinnamic acids profile of the dry bilberry shoot extract by high performance liquid chromatography.

Materials and Methods. As material for the study were used the dried extracts of bilberry shoots, obtained by the fractional maceration method from the crushed domestic origin bilberries shoots using alcohol-aqueous extractant with different ethanol content. The hydroxycinnamic acid standard samples (Sigma-Aldrich, Fluka) were used to identify the hydroxycinnamic acids. HPLC studies were performed with the liquid chromatography system with a diode array detector ("Waters 2960", USA). The chromatographic column XTerra C18 ("Waters", USA) with a size of 250x4,6 mm (5 $\mu \mathrm{m})$ at a temperature of $(25 \pm 1)^{\circ} \mathrm{C}$ was used.

Results and Discussion. HPLC profiles of the bilberry shoots dry extract contained chromatographic peaks corresponding to the retention times of chlorogenic, caffeic, ferulic, trans-p-coumaric and 3-hydroxycinnamic acids. By analyzing their electronic absorption spectra, the presence only of the chlorogenic and caffeic acids was confirmed. A substance with a relative retention time of 4.2 (relative to chlorogenic acid) is characterized by an absorption spectrum identical to the spectrum of chlorogenic acid, that is indicating that this substance is a hydroxycinnamic acid. The HPLC profile of the extract contains chromatographic peaks of three substances whose absorption spectra are similar to those of trans-pcoumaric acid. They may probably belong to isomers or derivatives of this acid. HPLC studies of the hydroxycinnamic acid

ISSN 2312-0967. Фармацевтичний часопис. 2019. № 4 
profiles of dry extracts obtained with the different ethanol content extractants were performed. It has been found that the content of caffeic acid in the dry extract increases but the content of chlorogenic acid decreases with decreasing ethanol content in the extractant. This is probably due with the intensification of the hydrolysis processes of chlorogenic acid to caffeic acid. This leads to a deeper study of this process in order to optimize the technology and to study the stability and storage conditions of the finished extract.

Conclusions. The chromatographic "fingerprinting" method is advisable to use to identify the bilberry shoots dry extract by detecting the chlorogenic, caffeic, unknown hydroxycinnamic (relative retention time is 4.2 relative the chlorogenic acid) and derivatives of the trans-p-coumaric acids in its HPLC profiles, obtained at a detection wavelength of 270 and $330 \mathrm{~nm}$. The comparison of the absorption spectra of the substances with the corresponding retention times is necessary simultaneously with the HPLC profiles studies. Due to the high content of individual hydroxycinnamic acids (chlorogenic, caffeic), the content of a single acid or of the hydroxycinnamic acids amount, in terms of chlorogenic acid, should be selected as one of the quantitative criteria for the quality of the dry extract.

Key words: bilberry shoots; dry extract; hydroxycinnamic acids; high performance liquid chromatography; chromatographic profile; electronic absorption spectra of hydroxycinnamic acids.

\title{
ХРОМАТОГРАФИЧЕСКИЙ ПРОФИЛЬ ГИДРОКСИКОРИЧНЫХ КИСЛОТ СУХОГО ЭКСТРАКТА ПОБЕГОВ ЧЕРНИКИ
}

\section{Л. В. Вронска}

\author{
Тернопольский национальный медицинский университет имени И. Я. Горбачевского МОз Украины \\ vronska_liudmyla@ukr.net
}

Цель работы. Изучение профиля гидроксикоричных кислот сухого экстракта побегов черники методом высокоэффрективной жидкостной хроматограсиии.

Материалы и методы. Материалом для исследования были сухие экстракты побегов черники, полученные методом дробной мацерации из измельченных побегов черники отечественного происхождения с помощью спиртово-водного экстрагента с различным содержанием этанола. Для идентификации гидроксикоричных кислот применяли стандартные образцы гидроксикоричных кислот (Sigma-Aldrich, Fluka). ВЭЖX-исследования проводили на жидкостном хроматографре с детектором диодной матрицей («Waters 2960», США). Использовали хроматограсрическую колонку XTerra C18 («Waters», США) размером 250x4,6 мм (5 мкм) при температуре (25 \pm 1$)^{\circ} \mathrm{C}$. Результаты и обсуждение. ВЭЖХ-просрили сухого экстракта побегов черники содержали хроматографические пики, отвечающие по времени удерживания хлорогеновой, кофейной, фреруловой, транс-п-кумаровой и 3-гидроксикоричной кислотам. Путем анализа их электронных спектров поглощения было подтверждено присутствие только хлорогеновой и кофейной кислот. Вещество с относительным временем удерживания 4,2 (относительно хлорогеновой кислоты) характеризуется спектром поглощения идентичным спектру хлорогеновой кислоты, что указывает на принадлежность этого вещества к гидроксикоричным кислотам. ВЭЖХ-профриль экстракта содержит хроматографические пики трех веществ, спектры поглощения которых идентичны спектру транс-п-кумаровой кислоты. Вероятно, они могут принадлежать к изомерам или производным этой кислоты. Проведены ВЭЖХ-исследования профилей гидроксикоричных кислот сухих экстрактов, полученных с помощью экстрагентов с различным содержанием этанола. Было установлено, что содержание косейной кислоты в сухом экстракте повышается, а хлорогеновой снижается со снижением содержания этанола в экстрагенте. Это, вероятно, связано с интенсификацией процессов гидролиза хлорогеновой кислоты и образованием кофейной. Это побуждает к более глубокому изучению данного процесса как с целью оптимизации технологии, так и с целью исследования стабильности и условий хранения готового экстракта.

Выводы. Для идентификации сухого экстракта побегов черники целесообразно применить метод хроматографического «отпечатка» путем выявления в ВЭЖХ-профилях экстракта, полученного при длине волны детектирования 270 и 330 нм, хлорогеновой, кофейной, неизвестной гидроксикоричной (с относительным временем удерживания 4,2 относительно хлорогеновой кислоты) и производных транс-п-кумаровой кислот. Одновременно с исследованием ВЭЖХ-проорилей необходимо сравнение спектров поглощения веществ с соответствующим временем удерживания. Учитывая высокое содержание отдельных гидроксикоричных кислот (хлорогеновой, кофейной), содержание отдельно взятой кислоты и/или суммы гидроксикоричных кислот, в пересчете на хлорогеновую, необходимо выбрать как один из количественных критериев качества сухого экстракта.

Ключевые слова: побеги черники; сухой экстракт; гидроксикоричные кислоты; высокоэффективная жидкостная хроматографрия; хроматографрический профиль; электронные спектры поглощения гидроксикоричных кислот.

ISSN 2312-0967. Pharmaceutical review. 2019. № 4 


\section{Список літератури}

1. Chapter 8-hydroxycinnamic acids: Natural sources, biosynthesis, possible biological activities, and roles in islamic medicine / Hesham R. El-Seedi, Eman A. Taher, Bassem Y. Sheikh [et al.] // Studies in Natural Products Chemistry. - 2018. - Vol. 55. - P. 269-292. doi: 10.1016/B978-0-444-64068-0.00008-5

2. Interactions of dietary fiber bound antioxidants with hydroxycinnamic and hydroxybenzoic acids in aqueous and liposome media / Ecem Evrim Çelik, Jose Manuel Amigo Rubio, Mogens Larsen Andersen [et al.] // Food Chemistry. - 2019. - Vol. 278. - P. 294-304. doi: 10.1016/j.foodchem.2018.11.068

3. Experimental confounding factors affecting stability, transport and metabolism of flavanols and hydroxycinnamic acids in Caco-2 cells. / M. Gómez-Juaristi, B. Sarria, L. Goya [et all.] // Food Research International. - 2020. - Vol. 129. - art. 108797. doi: 10.1016/j. foodres.2019.108797

4. 4-Hydroxycinnamic acid protects mice from cigarette smoke-induced pulmonary inflammation via MAPK pathways / Sung-Hyeuk Park, Je-Won Ko, Na-Rae Shin [et al.] // Food and Chemical Toxicology. - 2017. - Vol. 110. - P. 151-155. doi: 10.1016/j.fct.2017.10.027

5. Fuentes E. Mechanisms of endothelial cell protection by hydroxycinnamic acids / E. Fuentes, I. Palomo // Vascular Pharmacology. - 2014. - Vol. 63, Iss. 3. - P. 155161. doi: 10.1016/j.vph.2014.10.006

6. Weifeng Wang. Caffeic acid alleviates inflammatory response in rheumatoid arthritis fibroblast-like synoviocytes by inhibiting phosphorylation of IKB kinase $\alpha / \beta$ and IkBa / Weifeng Wang, Wei Sun, Lixia Jin // International Immunopharmacology. - 2017. - Vol. 48. - P. 61-66. doi: 10.1016/j.intimp.2017.04.025

7. Determination of hydroxycinnamic acids present in Rhododendron species / Abhinandan Shrestha, Inamullah Hakeem Said, Anne Grimbs [et al.] // Phytochemistry. - 2017. - Vol. 144. - P. 216-225. doi: 10.1016/j. phytochem.2017.09.018

8. Analysis of hydroxycinnamic acids derivatives in calafate (Berberis microphylla G. Forst) berries by liquid chromatography with photodiode array and mass spectrometry detection / A. Ruiz, C. Mardones, C. Vergara // Journal of Chromatography A. - 2013. - Vol. 1281. - P. 38-45. doi: 10.1016/j.chroma.2013.01.059

9. Yezerska O. Quantitative determination of hydroxycinnamic acids in chicory root / O. Yezerska, T. Kalynyuk, L. Vronska // Chemistry and Chemical Technology. - 2013. - No. 3. - P. 247-250. doi: 10.23939/ chcht07.03.247

10. Vronska L. V. Development of standardization method of elecampane rhizomes and roots (Inula helenium L.) for the hydroxycinnamic acids content / L. V. Vronska, A. Ye. Demyd, M. A. Ezhned // Фармацевтичний часопис. - 2016. - № 2. - С. 26-31. doi: 10.11603/23120967.2016.2.6646

11. Коваль В.М.Визначення екстракту ехінацеї у таблетках цинку аспарагінату 3 кислотою аскорбіновою та екстрактом ехінацеї пурпурової / В. М. Коваль, Л. В. Вронська // Актуальні питання фрармацевтичної і медичної науки та практики. 2012. - № 2. - C. 83-87.

12. Вронська Л. В. Дослідження щодо стандартизації трави меліси лікарської / Л. В. Вронська, А. Є. Демид // Управління, економіка та забезпечення якості в фрармації. - 2014. - № 2 (34). - С. 10-15.

13. Державна Фармакопея України: в 3 т. / Державне підприємство «Український науковий фрармакопейний центр якості лікарських засобів». - 2-е вид. - Харків : Державне підприємство «Український науковий фрармакопейний центр якості лікарських засобів». 2014. - T. 3. - 732 c.

14. Державна Фармакопея України / ДП «Український науковий фрармакопейний центр якості лікарських засобів». - 2-е вид. - Доповнення 1. - Харків : Державне підприємство «Український науковий фармакопейний центр якості лікарських засобів», 2016. - 360 c.

15. Державна Фармакопея України / ДП «Український науковий фрармакопейний центр якості лікарських засобів». - 2-е вид. - Доповнення 2. - Харків : Державне підприємство «Український науковий фрармакопейний центр якості лікарських засобів», 2018. - 336 c.

16. Державна Фармакопея України / ДП «Український науковий фрармакопейний центр якості лікарських засобів». - 2-е вид. - Доповнення 3. - Харків : Державне підприємство «Український науковий фармакопейний центр якості лікарських засобів», 2018. - 416 c.

17. Antioxidant properties of hydroxycinnamic acids: a review of structure- activity relationships / N. Razzaghi-Asl, J. Garrido, H. Khazraei [et al.] // Curr. Med. Chem. - 2013. - Vol. 20, No. 36. - P. 4436-4650. doi: $10.2174 / 09298673113209990141$

18. Effect of bilberries, lingonberries and cinnamon on cardiometabolic risk-associated markers following a hypercaloric-hyperlipidic breakfast / C. P. Busch Furlan, S. Costa Valle, M. R. Maróstica Jr. [et al.] // Journal of Functional Foods. - 2019. - Vol 60. - Art. 103443. doi: 10.1016/j.jff.2019.103443

19. Habanova M. Intake of bilberries (Vaccinium myrtillus $L$.) reduced risk factors for cardiovascular disease by inducing favorable changes in lipoprotein profiles I M. Habanova, J. A. Saraiva, M. Haban // Nutrition Research. - 2016. - Vol. 36, No. 12. - P. 1415-1422. doi: 10.1016/j.nutres.2016.11.010

20. Effect of bilberry extract (Vaccinium myrtillus L.) on drug-metabolizing enzymes in rats / P. J. Prokop, K. Lněničková, N. Cibiček, [et al.] // Food and Chemical Toxicology. - 2019. - Vol. 129. - P. 382-390. doi: 10.1016/j.fct.2019.04.051

21. Inhibition of human low-density lipoprotein oxidation by caffeic acid and other hydroxycinnamic acid derivatives / M. Nardini, M. D'Aquino, G. Tomassi [et al.] // Free radical Biology \& Medicine. - 1995. - Vol. 19, No. 5. P. 541-552. doi: 10.1016/0891-5849(95)00052-y

22. Khan F. A. Inhibitory mechanism against oxidative stress of caffeic acid / F. A. Khan, A. Maalik, G. Mur-

ISSN 2312-0967. Фармацевтичний часопис. 2019. № 4 
taza // J. Food and Drug analysis. - 2016. - Vol. 24. P. 695-702. doi: 10.1016/j.jfda.2016.05.003

23. Tundis R. Natural products as $\alpha$-amylase and $\alpha$-glucosidase inhibitors and their hypoglycaemic potential in the treatment of diabetes: an update / R. Tundis, M. R. Loizzo, F. Menichini // Mini-Reviews in Medicinal Chemistry. - 2010. - Vol. 10. - P. 315-331. doi:10.2174/138955710791331007

24. Comparison of phenolics and phenolic acid profiles in conjunction with oxygen radical absorbing capacity

\section{References}

1. El-Seedi HR, Taher EA, Sheikh BY, Anjum S, Saeed A, AlAjmi MF, Sherief MM et al. Chapter 8-hydroxycinnamic acids: Natural sources, biosynthesis, possible biological activities, and roles in islamic medicine. Studies in Natural Products Chemistry. 2018;55: 269-92. doi:10.1016/B978-0-444-64068-0.00008-5

2. Çelik EE, Rubio JMA, Andersen ML, Gökmen V. Interactions of dietary fiber bound antioxidants with hydroxycinnamic and hydroxybenzoic acids in aqueous and liposome media. Food Chemistry. 2019;278: 294-304. doi:10.1016/j.foodchem.2018.11.068

3. Gómez-Juaristi M, Sarria B, Goya L, Bravo-Clemente L, Mateos R. Experimental confounding factors affecting stability, transport and metabolism of flavanols and hydroxycinnamic acids in Caco-2 cells. Food Research International. 2020;129: art. 108797. doi:10.1016/j. foodres.2019.108797

4. Park Sung-Hyeuk, Ko Je-Won, Shin Na-Rae, Shin Dong-Ho, Cho Young-Kwon, Seo Chang-Seob, Kim Jong-Choon [et all.]. 4-Hydroxycinnamic acid protects mice from cigarette smoke-induced pulmonary inflammation via MAPK pathways. Food and Chemical Toxicology. 2017;110: 151-5. doi: 10.1016/j.fct.2017.10.027

5. Fuentes E, Palomo I. Mechanisms of endothelial cell protection by hydroxycinnamic acids. Vascular Pharmacology. 2014;63(3): 155-61. doi:10.1016/j. vph.2014.10.006

6. Weifeng Wang, Wei Sun, Lixia Jin. Caffeic acid alleviates inflammatory response in rheumatoid arthritis fibroblast-like synoviocytes by inhibiting phosphorylation of IкB kinase $\alpha / \beta$ and IкB $\alpha$. International Immunopharmacology. 2017;48: 61-6. doi:10.1016/j.intimp.2017.04.025

7. Shrestha A, Hakeem Said I, Grimbs A, Thielen N, Lansing L, Schepker H, Kuhnert N. Determination of hydroxycinnamic acids present in Rhododendron species. Phytochemistry. 2017;144: 216-25. doi: 10.1016/j.phytochem.2017.09.018

8. Ruiz A, Mardones C, Vergara C, Hermosín-Gutiérrez I, Dominguez $\mathrm{E}$. Analysis of hydroxycinnamic acids derivatives in calafate (Berberis microphylla G. Forst) berries by liquid chromatography with photodiode array and mass spectrometry detection. Journal of Chromatography A. 2013;1281: 38-45. doi:10.1016/j.chroma.2013.01.059

9. Yezerska O, Kalynyuk T, Vronska L. Quntitative determination of hydroxycinnamic acids in chicory. Chemistry and Chemical Technology. 2013;3: 247-50. doi:10.23939/chcht07.03.247
(ORAC) in berries of Vaccinium arctostaphylos L. and V. myrtillus L. / Nesrin Colak, Hülya Torun, Jiri Gruz [et al.] // Pol. J. Food Nutr. Sci. - 2016. - Vol. 66, No. 2. P. 85-91. doi: 10.1515/pjfns-2015-0053

25. Witzell J. Plant-part specific and temporal variation in phenolic compounds of boreal bilberry (Vaccinium myrtillus) plants / J. Witzell, Rolf Gref, Torgny Näsholm // Biochemical Systematics and Ecology. 2003. - Vol. 31. - P. 115-127. doi: 10.1016/S03051978(02)00141-2

10. Vronska LV, Demyd AYe, Ezhned MA. Development of standardization method of elecampane rhizomes and roots (Inula helenium L.) for the hydroxycinnamic acids content. Pharmaceutical Review. 2016;2: 26-31. doi:10.11603/2312-0967.2016.2.6646

11. Koval VM, Vronska LV. [Determination of echinacea extract in tablets with zinc aspartic and ascorbic acid and echinacea extract]. Aktualni pytannia farmatsevtychnoi i medychnoi nauky ta praktyky. 2012;2: 83-7. Ukrainian.

12. Vronska LV, Demyd AYe. [Studies on the standardization of Melissa officinalis herb]. Upravlinnia, ekonomika ta zabezpechennia yakosti v farmatsii. 2014;2(34): 1015. Ukrainian

13. The State Pharmacopoeia of Ukraine: in 3 vol. Kharkiv: Ukrainian Scientific Pharmacopoeia Center of Quality of Medicinal Products. Ed.2. [Державна Фармакопея України: в 3 т. / ДП «Український науковий фрармакопейний центр якості лікарських засобів». 2-е вид.] Kharkiv: Ukrainian Scientific Pharmacopoeia Center of Quality of Medicinal Products. 2014; Ukrainian.

14. The State Pharmacopoeia of Ukraine: Ukrainian Scientific Pharmacopoeia Center of Quality of Medicinal Products. Ed.2, addition 1. [Державна Фармакопея України / ДП «Український науковий фармакопейний центр якості лікарських засобів». - 2-е вид. - Доповнення 1.] Kharkiv: Ukrainian Scientific Pharmacopoeia Center of Quality of Medicinal Products.2016; Ukrainian.

15. The State Pharmacopoeia of Ukraine: Ukrainian Scientific Pharmacopoeia Center of Quality of Medicinal Products. Ed.2, addition 2. [Державна Фармакопея України / ДП «Український науковий фрармакопейний центр якості лікарських засобів». - 2-е вид. - Доповнення 2.] Kharkiv: Ukrainian Scientific Pharmacopoeia Center of Quality of Medicinal Products.2018; Ukrainian.

16. The State Pharmacopoeia of Ukraine: Ukrainian Scientific Pharmacopoeia Center of Quality of Medicinal Products. Ed.2, addition 3. [Державна Фармакопея України / ДП «Український науковий фрармакопейний центр якості лікарських засобів». - 2-е вид. - Доповнення 3.] Kharkiv: Ukrainian Scientific Pharmacopoeia Center of Quality of Medicinal Products. 2018; Ukrainian.

17. Razzaghi-Asl N, Garrido J, Khazraei H, Borges F, Firuzi O. Antioxidant properties of hydroxycinnamic acids: a review of structure-activity relationships Curr. Med. Chem. 2013;20(36): 4436-50. doi:10.2174/092986731 13209990141

ISSN 2312-0967. Pharmaceutical review. 2019. № 4 
18. Furlan CPB, Valle SC, Maróstica Jr MR, Östman E, Björck I, Tovar J. Effect of bilberries, lingonberries and cinnamon on cardiometabolic risk-associated markers following a hypercaloric-hyperlipidic breakfast. Journal of Functional Foods. 2019;60: 103443. doi:10.1016/j. jff.2019.103443

19. Habanova M, Saraiva JA, Haban M, Schwarzova M, Chlebo P, Predna L, Gažo J, Wyka J. Intake of bilberries (Vaccinium myrtillus L.) reduced risk factors for cardiovascular disease by inducing favorable changes in lipoprotein profiles. Nutrition Research. 2016;36(12): 1415-22. doi:10.1016/j.nutres.2016.11.010

20. Prokop $P J$, Lněničková $K$, Cibiček $N$, Kosina $P$ Tománková V, Jourová L, Láníčková T. Effect of bilberry extract (Vaccinium myrtillus L.) on drug-metabolizing enzymes in rats. Food and Chemical Toxicology. 2019;129: 382-90. doi: 10.1016/j.fct.2019.04.051

21. Nardini M, D'Aquino M, Tomassi G, Gentili V, Di Felice M, Scaccini C. Inhibition of human low-density lipoprotein oxidation by caffeic acid and other hydroxycinnamic acid derivatives. Free radical Biology \& Medicine. 1995;19(5):
541-52. doi: 10.1016/0891-5849(95)00052-y

22. Khan FA, Maalik A, Murtaza G. Inhibitory mechanism against oxidative stress of caffeic acid. J Food and Drug analysis. 2016;24: 695-702. doi: 10.1016/j. jfda.2016.05.003

23. Tundis R, Loizzo M R, Menichini F. Natural products as $\alpha$-amylase and $\alpha$-glucosidase inhibitors and their hypoglycaemic potential in the treatment of diabetes: an update. Mini-Reviews in Medicinal Chemistry. 2010;10: 315-31. doi:10.2174/138955710791331007

24. Colak N, Torun H, Gruz J, Strnad M, Subrtova M, Inceer $\mathrm{H}$, Ayaz FA. Comparison of phenolics and phenolic acid profiles in conjunction with oxygen radical absorbing capacity (ORAC) in berries of Vaccinium arctostaphylos L. and V. myrtillus L. Pol J Food Nutr Sci. 2016;66(2): 85-91. doi: 10.1515/pjfns-2015-0053

25. Witzell J, Gref R, Näsholm T. Plant-part specific and temporal variation in phenolic compounds of boreal bilberry (Vaccinium myrtillus) plants. Biochemical Systematics and Ecology. 2003;31: 115-27. doi: 10.1016/ S0305-1978(02)00141-2

\section{Відомості про авторів:}

Вронська Л. В. - канд. хім. н., доцент кафедри фрармації, Тернопільський національний медичний університет імені I. Я. Горбачевського МО3 України, Тернопіль, Україна. E-mail: vronska_liudmyla@ukr.net, ORCID 0000-0002-72236966

Information about the authors:

Vronska L.V. - PhD (Chemistry), Associate Professor of the Pharmacy Department, I. Horbachevsky Ternopil National Medical University, Ternopil, Ukraine. E-mail: vronska_liudmyla@ukr.net, ORCID 0000-0002-7223-6966 